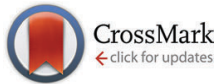

Cite this: Phys. Chem. Chem. Phys., 2016, 18, 23910

Received 24th March 2016 Accepted 3rd August 2016

DOI: 10.1039/c6сp01976e

www.rsc.org/pccp

\section{The reaction of $\mathrm{CF}_{2} \mathrm{Cl}_{2}$ with gas-phase hydrated electrons $\dagger$}

\author{
Jozef Lengyel, ${ }^{\star a}$ Christian van der Linde, ${ }^{a}$ Michal Fárník ${ }^{b}$ and Martin K. Beyer ${ }^{\star a}$ \\ The reaction of dichlorodifluoromethane $\left(\mathrm{CF}_{2} \mathrm{Cl}_{2}\right)$ with hydrated electrons $\left(\mathrm{H}_{2} \mathrm{O}\right)_{n}{ }^{-}(n=30-86)$ in the gas \\ phase was studied using Fourier transform ion cyclotron resonance (FT-ICR) mass spectrometry. The \\ hydrated electron reacts with $\mathrm{CF}_{2} \mathrm{Cl}_{2}$, forming $\left(\mathrm{H}_{2} \mathrm{O}\right)_{m} \mathrm{Cl}^{-}$with a rate constant of $(8.6 \pm 2.2) \times 10^{-10} \mathrm{~cm}^{3} \mathrm{~s}^{-1}$, \\ corresponding to an efficiency of $57 \pm 15 \%$. The reaction enthalpy was determined using nanocalorimetry, \\ revealing a strongly exothermic reaction with $\Delta H_{r}\left(C_{2} C_{2}, 298 \mathrm{~K}\right)=-208 \pm 41 \mathrm{~kJ} \mathrm{~mol}^{-1}$. The \\ combination of the measured reaction enthalpy with thermochemical data from the condensed phase \\ yields a $\mathrm{C}-\mathrm{Cl}$ bond dissociation enthalpy (BDE) $\Delta \mathrm{H}_{\mathrm{C}-\mathrm{Cl}}\left(\mathrm{CF}_{2} \mathrm{Cl}_{2}, 298 \mathrm{~K}\right)=355 \pm 41 \mathrm{~kJ} \mathrm{~mol}^{-1}$ that agrees \\ within error limits with the predicted values from quantum chemical calculations and published BDEs.
}

\section{Introduction}

Since the discovery of the atmospheric ozone hole chlorofluorocarbons (CFCs) have been recognized as one of the important players in ozone depletion. ${ }^{1,2}$ The most common $\mathrm{CFC}$ is dichlorodifluoromethane $\left(\mathrm{CF}_{2} \mathrm{Cl}_{2}\right)$ that was used in refrigerants due to its high latent heat, non-toxicity and inertness. The other factors in these processes are ice particles in polar stratospheric clouds (PSCs). ${ }^{3}$ Thus the chemistry, which involves not only the CFC in the gas phase, but also the environment of the ice particles, needs to be investigated.

The processes involved in ozone depletion are mostly driven by sunlight. Besides photochemistry on ice particles, ${ }^{4}$ electroninduced reactions have also received significant interest. The most prominent example is dissociative electron transfer (DET) on ice surfaces ${ }^{5-7}$ where electron transfer to CFCs was greatly enhanced by several orders of magnitude upon adsorption on ice. The mechanism was explained by the presence of a 'self-trapped', solvated excess electron in a polar medium such as water or ammonia. Based on the large enhancement of $\mathrm{Cl}^{-}$generation from the DET to CFCs on ices, Lu and Sanche ${ }^{8,9}$ proposed the cosmic-ray-driven electron reaction model for ozone depletion, short CRE mechanism, as an additional potential source of $\mathrm{Cl}^{\circ}$ radicals. This mechanism initiated a controversial debate..$^{8,10-15}$

$\mathrm{Cl}^{-}$enhancement was also observed in other experiments ${ }^{16,17}$ and it was interpreted as an attachment of low energy secondary

\footnotetext{
${ }^{a}$ Institut für Ionenphysik und Angewandte Physik, Leopold-Franzens-Universität Innsbruck, Technikerstraße 25, 6020 Innsbruck, Austria.

E-mail: jozef.lengyel@uibk.ac.at,martin.beyer@uibk.ac.at

${ }^{b}$ J. Heyrovský Institute of Physical Chemistry v.v.i., Czech Academy of Sciences, Dolejškova 3, 18223 Prague, Czech Republic

$\dagger$ Electronic supplementary information (ESI) available: Conversion of $\Delta E_{\text {raw }}$ to $\Delta H_{298 \text { K. }}$ See DOI: $10.1039 / \mathrm{c} 6 \mathrm{cp} 01976 \mathrm{e}$
}

electrons to $\mathrm{CF}_{2} \mathrm{Cl}_{2}$ solvated in a polar medium. $\mathrm{CF}_{2} \mathrm{Cl}_{2}$ is then decomposed and $\mathrm{Cl}^{-}$is generated due to tunnelling of the solvated electron. In contrast to this interpretation, the dissociative electron attachment (DEA) cross-sections of mixed $\mathrm{CF}_{2} \mathrm{Cl}_{2} / \mathrm{NH}_{3}$ clusters did not exhibit any enhancement for electron energies in the range of $0-20 \mathrm{eV}^{18}{ }^{18}$ In condensed phase electrochemistry, DET of carbon-halogen bonds has been extensively studied. ${ }^{19}$ A sticky DET mechanism with the $\mathrm{Cl}^{-}$and $\mathrm{CCl}_{3}{ }^{\bullet}$ fragments bound by a solvent cage was established by Pause et al. ${ }^{20}$ for DET of $\mathrm{CCl}_{4}$ in $N, N^{\prime}$-dimethylformamide, but the strength of the interaction was found to decrease with increasing polarity of the solvent. ${ }^{21}$

DEA to gas-phase $\mathrm{CF}_{2} \mathrm{Cl}_{2}$ is an efficient process due to the high electron affinity of halogen atoms. ${ }^{22}$ Illenberger $e t$ al. ${ }^{23,24}$ observed that DEA to $\mathrm{CF}_{2} \mathrm{Cl}_{2}$ at electron energies close to $0 \mathrm{eV}$ occurs via reaction (1), with large cross-sections.

$$
\mathrm{CF}_{2} \mathrm{Cl}_{2}+\mathrm{e}^{-} \rightarrow \mathrm{CF}_{2} \mathrm{Cl}_{2}{ }^{*-} \rightarrow \mathrm{Cl}^{-}+\mathrm{CF}_{2} \mathrm{Cl}^{\bullet}
$$

However, there are very few free electrons in the atmosphere below $50 \mathrm{~km}$ altitude, ${ }^{25}$ because they are quickly captured by abundant molecules, in particular $\mathrm{O}_{2}{ }^{26}{ }^{26}$ Therefore, in the CRE mechanism it is assumed that the PSC particles are able to stabilize solvated electrons generated by ionizing radiation within a condensed phase particle. If $\mathrm{CF}_{2} \mathrm{Cl}_{2}$ is also condensed in the particle, DET with formation of $\mathrm{Cl}^{-}$may take place. For the liquid phase, it has been shown already in 1971 by pulse radiolysis studies in bulk aqueous solution that thermalized hydrated electrons react rapidly with CFCs to produce $\mathrm{Cl}^{-}$ions. ${ }^{27}$

Previous studies in our group have shown that reductive cleavage of carbon-halogen bonds, i.e. DET, competes with the first step of Birch reduction in reactions of chlorobenzene as well as di- and trifluorobenzenes with gas-phase hydrated electrons $\left(\mathrm{H}_{2} \mathrm{O}\right)_{n}{ }^{-28,29}$ In order to test whether fully thermalized solvated 
electrons are capable of inducing DET in CFCs, we examine the reaction of $\mathrm{CF}_{2} \mathrm{Cl}_{2}$ and hydrated electrons $\left(\mathrm{H}_{2} \mathrm{O}\right)_{n}{ }^{-}$in the cluster size range $n=30-86$. We report a systematic study on the reaction kinetics. Applying nanocalorimetry, we extract the reaction enthalpy from the experimental data. In combination with literature thermochemistry from the condensed phase, the $\mathrm{C}-\mathrm{Cl}$ bond dissociation enthalpy (BDE) of gas-phase $\mathrm{CF}_{2} \mathrm{Cl}_{2}$ is derived and compared with literature values as well as highlevel quantum chemical calculations. We discuss the observed results in comparison with DET studies in bulk ice and photodissociation experiments in water clusters.

\section{Experiment}

The experiments are performed using a modified Bruker/ Spectrospin CMS47X FT-ICR mass spectrometer, equipped with a 4.7 T superconducting magnet, a Bruker infinity cell, and an APEX III data station. ${ }^{30,31}$ Hydrated electrons $\left(\mathrm{H}_{2} \mathrm{O}\right)_{n}{ }^{-}$are generated in a home built external source ${ }^{31,32}$ by laser vaporization of a solid zinc target and supersonic expansion of the hot plasma in a helium/water gas pulse. ${ }^{33,34}$ The skimmed $\left(\mathrm{H}_{2} \mathrm{O}\right)_{n}{ }^{-}$cluster beam is transferred via an electrostatic lens system through differential pumping stages into the ultra-high vacuum (UHV) region of the mass spectrometer, with a background pressure below $5 \times 10^{-10} \mathrm{mbar}$, and stored in the ICR cell. $\mathrm{CF}_{2} \mathrm{Cl}_{2}$ is introduced into the UHV region of the mass spectrometer as a gas through a leak valve at constant pressures in the range of $0.5-1.1 \times 10^{-8} \mathrm{mbar}$. The purity of the reactant is checked using electron ionization and high resolution mass spectrometry directly in the ICR cell.

To determine the rate constant, reactions are monitored by recording mass spectra as a function of time. The intensities of reactant and product clusters in the mass spectra are summed over all cluster sizes. While the experiments are conducted at room temperature, the internal temperature of $\left(\mathrm{H}_{2} \mathrm{O}\right)_{n}{ }^{-}$clusters is a result of the interplay between radiative heating by black-body radiation and evaporative cooling. ${ }^{35}$ In combination with the caloric curves measured by Hock et al. ${ }^{36}$ this places the internal temperature of the clusters in the range of 90-120 K.

Thermochemistry is investigated using nanocalorimetry. ${ }^{30,37}$ The heat released during the reaction is extracted by quantitative modelling of the average size of reactant and product clusters as a function of time, taking into account blackbody radiation induced dissociation (BIRD). ${ }^{35,38-41}$ The method was introduced by Höckendorf et al. ${ }^{30}$ in reactions of $\left(\mathrm{H}_{2} \mathrm{O}\right)_{n}{ }^{-}$with $\mathrm{O}_{2}$ and $\mathrm{CO}_{2}$.

To extract the reaction enthalpy from the mass spectra, the average cluster size of reactant and product species is calculated. The results are fitted with a genetic algorithm with the following differential equations:

$$
\begin{gathered}
\mathrm{d} N_{\mathrm{R}}=-k_{\mathrm{f}}\left(N_{\mathrm{R}}-N_{0, \mathrm{R}}\right) \mathrm{d} t \\
\mathrm{~d} N_{\mathrm{P}}=-k_{\mathrm{f}}\left(N_{\mathrm{P}}-N_{0, \mathrm{P}}\right) \mathrm{d} t+\left(N_{\mathrm{R}}-\Delta N_{\text {vap }}-N_{\mathrm{P}}\right)\left(\frac{k I_{\mathrm{R}}}{I_{\mathrm{P}}}\right) \mathrm{d} t
\end{gathered}
$$

Eqn (2) and the first term in eqn (3) describe BIRD of water clusters, with $k_{\mathrm{f}}$ describing the linear dependence on cluster size. $N_{0, \mathrm{R}}, N_{0, \mathrm{P}}$ account for the contribution of the ionic core to the IR absorption cross-sections. The second term in eqn (3) describes the evaporation of water molecules due to the reaction enthalpy released in the water cluster. The average number of evaporated water molecules $\Delta N_{\text {vap }}$ is the key result of the fit.

The experiments are assisted by quantum chemical calculations at the Gaussian-4 (G4) level ${ }^{42}$ using the Gaussian09 program package $^{43}$ to support the experimentally observed BDE of the $\mathrm{CF}_{2} \mathrm{Cl}_{2}$ molecule. In general, G4 level calculations exhibit an average absolute deviation from experiment of $3.5 \mathrm{~kJ} \mathrm{~mol}^{-1}$.

\section{Results}

Fig. 1 shows the mass spectra of the reaction of $\mathrm{CF}_{2} \mathrm{Cl}_{2}$ with $\left(\mathrm{H}_{2} \mathrm{O}\right)_{n}{ }^{-}$. The reaction leads to the formation of hydrated chloride ions and $\mathrm{CF}_{2} \mathrm{Cl}^{\bullet}$ radicals, which evaporate from the water cluster, reaction (4).

$\mathrm{CF}_{2} \mathrm{Cl}_{2}+\left(\mathrm{H}_{2} \mathrm{O}\right)_{n}{ }^{-} \rightarrow\left(\mathrm{H}_{2} \mathrm{O}\right)_{m} \mathrm{Cl}^{-}+\mathrm{CF}_{2} \mathrm{Cl}^{\bullet}+(n-m) \mathrm{H}_{2} \mathrm{O}$

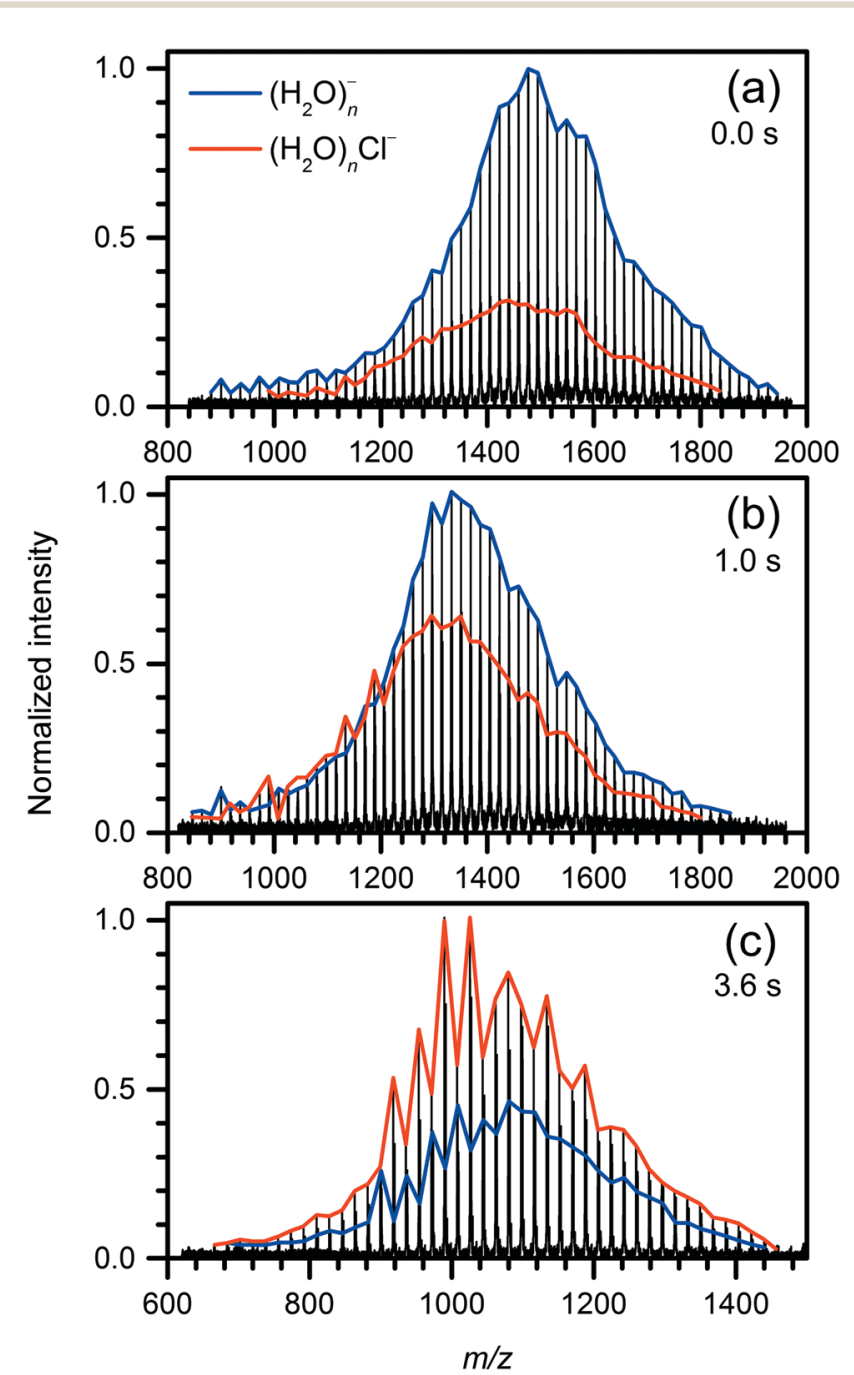

Fig. 1 Mass spectra of the reaction of $\mathrm{CF}_{2} \mathrm{Cl}_{2}$ with hydrated electrons (blue line) after (a) 0.0 , (b) 1.0 , and (c) $3.6 \mathrm{~s}$. $\left(\mathrm{H}_{2} \mathrm{O}\right)_{\mathrm{m}} \mathrm{Cl}^{-}$(red line) as the product is present already at nominal $0.0 \mathrm{~s}$ due to the $2 \mathrm{~s}$ filling cycle. 
At initial $0 \mathrm{~s}$, the mass spectrum is dominated by hydrated electrons. However, a small amount of the product ions is present. Some clusters have reacted during the accumulation in the ICR cell, which takes $2 \mathrm{~s}$. The intensity of the product ions increases with the delay time. After $1 \mathrm{~s}$, the product ions represent more than $50 \%$ of the hydrated electron intensity. The product ions start to dominate after $1.5 \mathrm{~s}$. At longer times, the shift of the cluster size distribution to smaller values is clearly visible. Both species undergo BIRD and continuously lose water ligands. After $30 \mathrm{~s}$, the clusters have lost almost all water molecules, and $\left(\mathrm{H}_{2} \mathrm{O}\right)_{m} \mathrm{Cl}^{-}, m=3-6$, is present in the mass spectrum.

To elucidate the reaction rate, the total intensities are plotted as a function of time. The intensities of reactant and product clusters in the mass spectra are summed over all cluster sizes and normalized. The reaction kinetics is quantitatively analysed for the first 4-8 s, depending on the initial cluster size. For $n<30$, blackbody radiation induced electron detachment occurs, which interferes with the quantitative analysis. ${ }^{33,44}$ Thus all quantitative fits are stopped when the lower end of the cluster size distribution reaches $n=30$. Fig. 2a shows the kinetic fit using a pseudo-first-order rate law. The resulting first order rate constant $k_{\text {rel }}\left[\mathrm{s}^{-1}\right]$ is converted to a pressure corrected absolute rate constant. A relative error of $\pm 25 \%$ is determined by the uncertainty of the pressure gauge. Since the $\mathrm{CF}_{2} \mathrm{Cl}_{2}$ pressure is a critical parameter for the absolute rate constant determination, the measurements were performed at different pressures repeatedly on different days to minimize any uncertainty. The results of each measurement are shown in Table 1 . The measured experimental rate constants $k_{\mathrm{abs}}$ are compared with the calculated collision rates to determine the reaction efficiency. We have shown previously that average dipole orientation (ADO) theory, ${ }^{45-48}$ which describes the ion as a point charge, underestimates the collision rate of clusters with more than 10 water molecules $\left(k_{\mathrm{ADO}}=6.1 \times 10^{-10} \mathrm{~cm}^{3} \mathrm{~s}^{-1}\right.$ for reaction with $\mathrm{CF}_{2} \mathrm{Cl}_{2}$ ). We therefore use models that account for the geometric size of the water cluster, in particular the hard sphere average dipole orientation, $k_{\mathrm{HSA}}=1.0 \times 10^{-9} \mathrm{~cm}^{3} \mathrm{~s}^{-1}$, and the surface charge capture model, $k_{\mathrm{SCC}}=2.0 \times 10^{-9} \mathrm{~cm}^{3} \mathrm{~s}^{-1} \cdot{ }^{49}$ Earlier studies in our group indicate that the actual collision rate of ionic water clusters lies between the two models. ${ }^{50-54}$ The reaction efficiency can thus be determined using eqn (5).

$$
\Phi=2 k_{\mathrm{abs}} /\left(k_{\mathrm{HSA}}+k_{\mathrm{SCC}}\right)
$$

Averaging over all experiments, we arrive at an absolute rate constant of $k_{\mathrm{abs}}=8.6 \pm 2.2 \times 10^{-10} \mathrm{~cm}^{3} \mathrm{~s}^{-1}$, which corresponds to an efficiency $\Phi=57 \pm 15 \%$. This means that about one out of two collisions is reactive.

The mass spectra reveal that the $\left(\mathrm{H}_{2} \mathrm{O}\right)_{m} \mathrm{Cl}^{-}$ions have a slightly lower mean cluster size than the hydrated electrons $\left(\mathrm{H}_{2} \mathrm{O}\right)_{n}{ }^{-}$. This difference indicates that water molecules are lost due to exothermic reaction. Nanocalorimetry is employed, in which the average number of evaporated water molecules is determined. ${ }^{30}$ The mean cluster sizes for reactants and products as well as their difference were plotted as a function of time (Fig. 2b and c). A nanocalorimetric fit reveals that the reaction leads to the evaporation of $4.9 \pm 0.9$ water molecules.

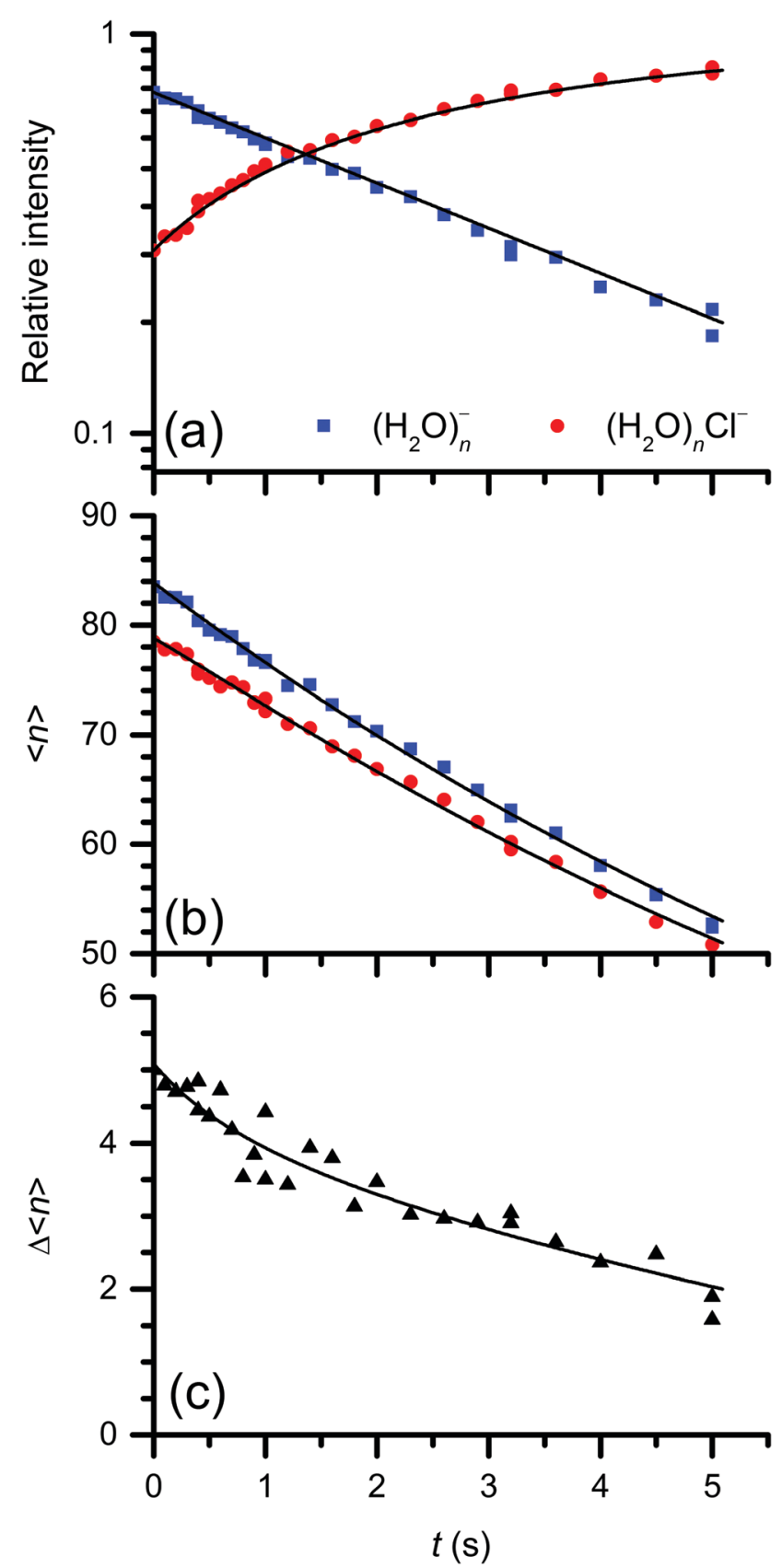

Fig. 2 (a) Kinetic and ( $b$ and $c$ ) nanocalorimetric analysis of the reaction of $\mathrm{CF}_{2} \mathrm{Cl}_{2}$ with hydrated electrons $\left(\mathrm{H}_{2} \mathrm{O}\right)_{n}{ }^{-}$at room temperature. Panel (a) represents the pseudo-first-order kinetic fit of $\left(\mathrm{H}_{2} \mathrm{O}\right)_{n}{ }^{-}$(blue squares) as the reactant and $\left(\mathrm{H}_{2} \mathrm{O}\right)_{m} \mathrm{Cl}^{-}$(red circles) as the product species. Panel (b) shows the fit of the cluster mean sizes for both species, and panel (c) illustrates the fit of their size difference (black diamonds).

The energy required to evaporate a single water molecule from the cluster is $\Delta E_{\mathrm{vap}}=43.3 \pm 3.1 \mathrm{~kJ} \mathrm{~mol}{ }^{-1} \cdot{ }^{36,55}$ The total energy release is almost identical to the absolute value of the room temperature reaction enthalpy, with minor corrections and a small contribution to the uncertainty. ${ }^{30,50}$ Then $\Delta E_{\text {raw }}$ can be calculated using eqn (6), which is converted to room temperature enthalpy $\Delta H_{\mathrm{r}}\left(\mathrm{CF}_{2} \mathrm{Cl}_{2}, 298 \mathrm{~K}\right)$ as detailed in the accompanying ESI. $\dagger$ 
Table 1 Kinetic and nanocalorimetric analysis of each data set

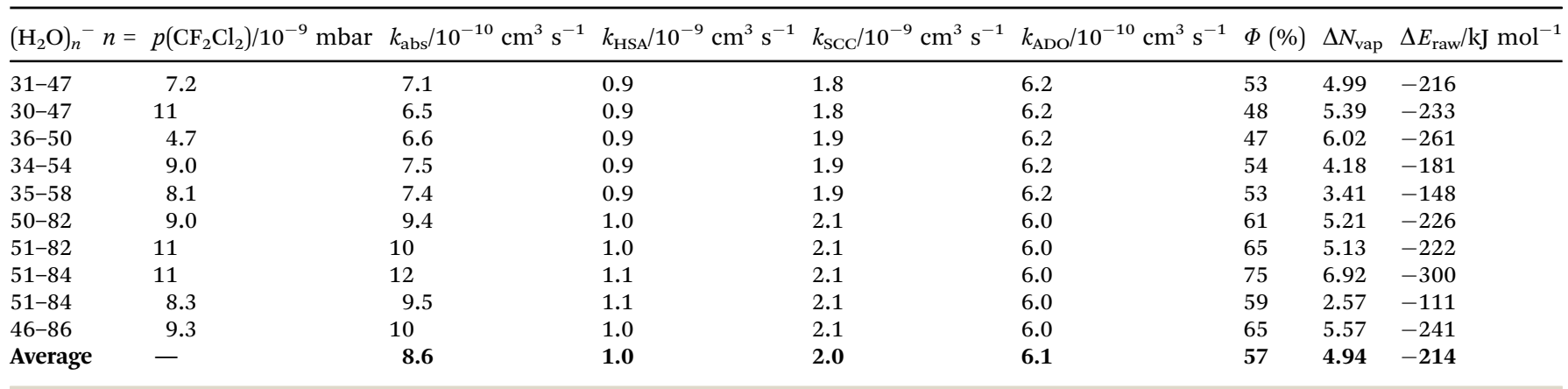

Table 2 Thermochemical cycle for the $\mathrm{Cl}-\mathrm{CF}_{2} \mathrm{Cl} \mathrm{BDE}$

\begin{tabular}{lcl}
\hline Reaction & $\begin{array}{c}\Delta H_{\mathrm{r}}(298 \mathrm{~K}) / \\
\mathrm{kJ} \mathrm{mol}^{-1}\end{array}$ & Ref. \\
\hline $\mathrm{H}^{+}(\mathrm{g})+\mathrm{e}^{-}(\mathrm{g}) \rightarrow \mathrm{H}^{+}(\mathrm{aq})+\mathrm{e}^{-}(\mathrm{aq})$ & -1261.9 & 56 \\
$\mathrm{H}^{+}(\mathrm{aq})+\mathrm{Cl}^{-}(\mathrm{aq}) \rightarrow \mathrm{HCl}(\mathrm{g})$ & 74.48 & 58 \\
$\mathrm{HCl}(\mathrm{g}) \rightarrow \mathrm{H}(\mathrm{g})+\mathrm{Cl}(\mathrm{g})$ & 431.58 & 57 \\
$\mathrm{H}(\mathrm{g}) \rightarrow \mathrm{H}^{+}(\mathrm{g})+\mathrm{e}^{-}(\mathrm{g})$ & 1318.4 & 59 \\
$\mathrm{CF}_{2} \mathrm{Cl}_{2}(\mathrm{~g})+\mathrm{e}^{-}(\mathrm{aq}) \rightarrow \mathrm{CF}_{2} \mathrm{Cl}(\mathrm{g})+\mathrm{Cl}^{-}(\mathrm{aq})$ & -208 & Our work \\
$\mathbf{C F}_{2} \mathbf{C l}_{2}(\mathrm{~g}) \rightarrow \mathbf{C F}_{2} \mathbf{C l}(\mathrm{g})+\mathbf{C l}(\mathrm{g})$ & $\mathbf{3 5 5}$ & Sum
\end{tabular}

$$
\begin{gathered}
\Delta E_{\text {raw }}=-\Delta N_{\text {vap }} \Delta E_{\text {vap }}=-214 \pm 41 \mathrm{~kJ} \mathrm{~mol}^{-1} \\
\Delta H_{\mathrm{r}}\left(\mathrm{CF}_{2} \mathrm{Cl}_{2}, 298 \mathrm{~K}\right)=-208 \pm 41 \mathrm{~kJ} \mathrm{~mol}^{-1}
\end{gathered}
$$

The observed electron transfer reaction of $\mathrm{CF}_{2} \mathrm{Cl}_{2}$ with $\left(\mathrm{H}_{2} \mathrm{O}\right)_{n}{ }^{-}$is strongly exothermic. To the best of our knowledge, no thermochemical data on the reaction of hydrated electrons with $\mathrm{CF}_{2} \mathrm{Cl}_{2}$ have been reported so far.

To compare the measured results with literature thermochemistry, we use the observed $\Delta H_{\mathrm{r}}$ in combination with reaction enthalpies from the condensed phase to calculate the $\mathrm{BDE}$ of $\mathrm{Cl}-$ $\mathrm{CF}_{2} \mathrm{Cl}$ bond cleavage. The same approach was successfully used previously on $\mathrm{SF}_{6}$ as a benchmark for nanocalorimetry. ${ }^{50} \mathrm{BDE}$ is calculated from established data, namely the hydration energy of the electron, ${ }^{56}$ the dissociation enthalpy of $\mathrm{HCl}^{57}$ the solution enthalpy of gaseous $\mathrm{HCl}^{58}$ and the ionization energy of the hydrogen atom. ${ }^{59} \mathrm{~A}$ thermochemical cycle including all reaction steps is summarized in Table 2. BDE as the enthalpy change of the overall reaction is calculated as the sum of the reaction enthalpies of the partial equations. This results in the $\mathrm{C}-\mathrm{Cl} \mathrm{BDE}$ of $\mathrm{CF}_{2} \mathrm{Cl}_{2}, \Delta H_{\mathrm{C}-\mathrm{Cl}}\left(\mathrm{CF}_{2} \mathrm{Cl}_{2}, 298 \mathrm{~K}\right)=355 \pm 41 \mathrm{~kJ} \mathrm{~mol}^{-1}$.

In addition, the thermochemistry of the $\mathrm{C}-\mathrm{Cl}$ bond cleavage of $\mathrm{CF}_{2} \mathrm{Cl}_{2}$ is derived by $\mathrm{G} 4$ calculations, in which $\mathrm{BDE}$ is obtained from the total enthalpies at 298.15 K. The calculated BDE amounts to $337 \mathrm{~kJ} \mathrm{~mol}^{-1}$. This lies within $18 \mathrm{~kJ} \mathrm{~mol}^{-1}$ of the experimental value. Both values agree within error limits with the published BDE of $346.0 \pm 13.4 \mathrm{~kJ} \mathrm{~mol}^{-1}$ that was calculated from the standard enthalpies of formation. ${ }^{60,61}$

\section{Discussion}

At first sight, the high exothermicity of reaction (4) may be surprising, given that the $\mathrm{C}-\mathrm{Cl}$ bond dissociation energy of $355 \pm 41 \mathrm{~kJ} \mathrm{~mol}^{-1}$ is close to the electron affinity of the $\mathrm{Cl}$ atom,
$348 \mathrm{~kJ} \mathrm{~mol}^{-1}$. However, the additional energy is supplied by the much stronger interaction of the $\mathrm{Cl}^{-}$ion with the solvent environment compared to the hydrated electron. Essentially, hydration promotes DET.

The mechanism of the reaction is straightforward. In the first step, the solvated electron moves to the $\sigma^{*}$ orbital of one of the $\mathrm{C}-\mathrm{Cl}$ bonds, reducing the bond order from 1 to 0.5 . Water molecules rearrange to solvate the incipient chloride ion, which further weakens the bond until it is broken and the $\mathrm{CF}_{2} \mathrm{Cl}^{\bullet}$ radical is released. Whether a local bound minimum between the $\mathrm{Cl}^{-}$and $\mathrm{CF}_{2} \mathrm{Cl}^{\bullet}$ exists, i.e. whether the DET corresponds to a sticky DET in aqueous solution, ${ }^{19}$ cannot be determined on the basis of our experiments. We therefore depicted potential curves for both scenarios in Fig. 3. This mechanism can be discussed in connection with two other experiments mentioned in the introduction: the photodissociation of $\mathrm{CF}_{2} \mathrm{Cl}_{2}{ }^{4,62}$ and the DET mechanism to CFCs on ices. ${ }^{5-9}$

First, we discuss the photodissociation of $\mathrm{CF}_{2} \mathrm{Cl}_{2}$; it is a similar process to DET in the sense that the electron is promoted by a UV photon to the antibonding $\sigma^{*}$ orbital on one of the $\mathrm{C}-\mathrm{Cl}$ bonds. ${ }^{62}$ In our recent study of this process on large water clusters ${ }^{4}$ we have not seen any evidence for free $\mathrm{Cl}$ fragments. Accompanying theoretical calculations revealed a halogen bond ${ }^{63}$ between $\mathrm{Cl}$ and $\mathrm{O}$ atoms of water molecules. Thus the $\mathrm{CF}_{2} \mathrm{Cl}_{2}$ molecule was bound to the ice nanoparticles with the $\mathrm{Cl}$ atoms oriented towards the cluster and the $\mathrm{Cl}$ fragment was caged by the cluster after photodissociation. ${ }^{4}$ This is consistent with the present observation that the $\mathrm{Cl}^{-}$

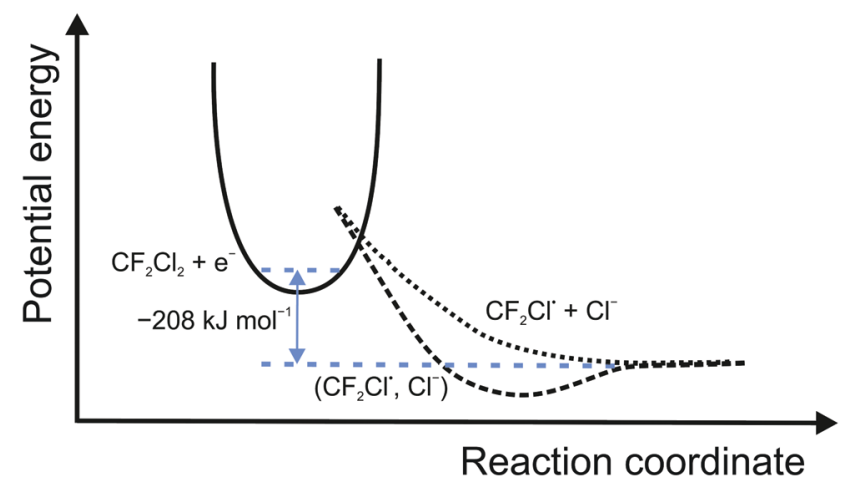

Fig. 3 Schematic potential energy curves for sticky (dashed) or nonsticky (dotted) DET of a hydrated electron to $\mathrm{CF}_{2} \mathrm{Cl}_{2}$. 
fragment of DET on water clusters remains with water clusters generating the observed $\left(\mathrm{H}_{2} \mathrm{O}\right)_{m} \mathrm{Cl}^{-}$products, thus further supporting our previous proposal of halogen bonding between the $\mathrm{CF}_{2} \mathrm{Cl}_{2}$ molecule and water clusters. It also matches the observed efficiency of $57 \%$, if one assumes that $\mathrm{CF}_{2} \mathrm{Cl}_{2}$ has to collide with the water cluster with the chlorine atoms facing the water network.

Concerning the DET mechanism to CFCs (and other molecules) on ices, it was proposed to proceed via so-called presolvated electrons with binding energies of about $1.3 \mathrm{eV}$ below the vacuum level. ${ }^{8,64-67}$ The vertical detachment energy of solvated electrons in water clusters strongly depends on the cluster size. In the size range studied here, the VDE of $\left(\mathrm{H}_{2} \mathrm{O}\right)_{n}{ }^{-}, n=30-86$, ranges from $1.46 \mathrm{eV}$ to $2.00 \mathrm{eV} .^{68}$ Extrapolation of cluster values to the bulk yields VDEs ranging from $3.3 \mathrm{eV}$ to $4.0 \mathrm{eV}$ in the literature. ${ }^{68-71}$ The VDE of bulk water is directly accessible from liquid jet measurements, where values of $3.3 \mathrm{eV}$ have been reported. ${ }^{72,73}$ No adiabatic values are available for neat water clusters, but Donald et al. studied the hydration of free electrons in $\mathrm{La}\left(\mathrm{H}_{2} \mathrm{O}\right)_{n}{ }^{3+}, n=42-160 .{ }^{74}$ From this study, they extrapolated a bulk hydration enthalpy of $-1.3 \mathrm{eV}$ for the electron, identical to the value suggested for the presolvated electron. Direct measurements of the adiabatic hydration enthalpy of an electron in bulk water usually refer to the absolute hydration enthalpy of a proton, which is not precisely known. Taking for example the value reported by Shiraishi et $a l^{56}$ referenced to $\Delta H_{\text {hyd }}\left(\mathrm{H}^{+}\right)=-1090 \mathrm{~kJ} \mathrm{~mol}^{-1}$, which is the textbook standard, results in $\Delta H_{\text {hyd }}\left(\mathrm{e}^{-}\right)=-172 \mathrm{~kJ} \mathrm{~mol}^{-1}$ or $-1.8 \mathrm{eV}$. It should be noted that the thermochemical analysis presented here does not rely on the absolute hydration enthalpy of a proton or an electron, but only on their combined value, which should be very reliable. Since hydrated electrons in the excited state relax within $400 \mathrm{fs}$ $(n=25)$ to 1 ps (bulk) to the electronic ground state, ${ }^{75}$ we can safely conclude that in our clusters, the electrons are in the electronic ground state. This implies that dissociative electron transfer to $\mathrm{CF}_{2} \mathrm{Cl}_{2}$ in the condensed phase does not require a presolvated state, which is in agreement with the earlier results from pulse radiolysis in bulk aqueous solution. ${ }^{27}$

\section{Conclusions}

As previously observed in pulse radiolysis studies in bulk aqueous solution, our results with gas-phase hydrated electrons confirm that fully thermalized hydrated electrons in their electronic ground state are able to induce bond cleavage in $\mathrm{CF}_{2} \mathrm{Cl}_{2}$, analogous to the DET mechanism proposed for PSCs. The reaction is efficient and very exothermic. Nanocalorimetry combined with condensed phase literature thermochemistry yields thermochemical data that are consistent with literature values, as well as our own quantum chemical calculations. All these arguments together are consistent with the interpretation that $\mathrm{CF}_{2} \mathrm{Cl}_{2}$ undergoes DET in condensed aqueous environments, if thermalized hydrated electrons are present. Whether or not this mechanism is actually relevant for stratospheric ozone destruction is a different question, which cannot be answered on the basis of the present laboratory studies.

\section{Acknowledgements}

J. L. acknowledges support from the Lise Meitner Programme of the Austrian Science Fund (FWF): project No. M1983-N34. M. F. acknowledges the Czech Science Foundation grant No. 14-08937S.

\section{References}

1 F. S. Rowland and M. J. Molina, Rev. Geophys., 1975, 13, 1.

2 M. J. Molina and F. S. Rowland, Nature, 1974, 249, 810.

3 S. Solomon, R. R. Garcia, F. S. Rowland and D. J. Wuebbles, Nature, 1986, 321, 755.

4 V. Poterya, J. Kočišek, J. Lengyel, P. Svrčková, A. Pysanenko, D. Hollas, P. Slavíček and M. Fárník, J. Phys. Chem. A, 2014, 118, 4740.

5 Q.-B. Lu and L. Sanche, Phys. Rev. B: Condens. Matter Mater. Phys., 2001, 63, 153403.

6 Q.-B. Lu and T. E. Madey, Surf. Sci., 2000, 451, 238.

7 Q.-B. Lu and T. E. Madey, J. Chem. Phys., 1999, 111, 2861.

8 Q.-B. Lu, Phys. Rep., 2010, 487, 141.

9 Q.-B. Lu and L. Sanche, Phys. Rev. Lett., 2001, 87, 78501.

10 J.-U. Grooß and R. Müller, Atmos. Environ., 2011, 45, 3508.

11 R. Müller, Phys. Rev. Lett., 2003, 91, 58502.

12 Q.-B. Lu and L. Sanche, Phys. Rev. Lett., 2002, 89, 219804.

13 P. K. Patra and M. S. Santhanam, Phys. Rev. Lett., 2002, 89, 219803.

14 Q.-B. Lu and L. Sanche, Phys. Rev. Lett., 2002, 89, 219802.

15 N. R. P. Harris, J. C. Farman and D. W. Fahey, Phys. Rev. Lett., 2002, 89, 219801.

16 N. S. Faradzhev, C. C. Perry, D. O. Kusmierek, D. H. Fairbrother and T. E. Madey, J. Chem. Phys., 2004, 121, 8547.

17 S. Solovev, D. O. Kusmierek and T. E. Madey, J. Chem. Phys., 2004, 120, 968.

18 J. Langer, S. Matt, M. Meinke, P. Tegeder, A. Stamatovic and E. Illenberger, J. Chem. Phys., 2000, 113, 11063.

19 A. Houmam, Chem. Rev., 2008, 108, 2180.

20 L. Pause, M. Robert and J.-M. Savéant, J. Am. Chem. Soc., 2000, 122, 9829.

21 L. Pause, M. Robert and J.-M. Savéant, J. Am. Chem. Soc., 2001, 123, 11908.

22 K. Graupner, S. A. Haughey, T. A. Field, C. A. Mayhew, T. H. Hoffmann, O. May, J. Fedor, M. Allan, I. I. Fabrikant, E. Illenberger, M. Braun, M.-W. Ruf and H. Hotop, J. Phys. Chem. A, 2010, 114, 1474.

23 E. Illenberger, Ber. Bunsenges. Phys. Chem., 1982, 86, 252.

24 E. Illenberger, H.-U. Scheunemann and H. Baumgärtel, Chem. Phys., 1979, 37, 21.

25 J. Kaplan and C. A. Barth, Proc. Natl. Acad. Sci. U. S. A., 1958, 44, 105.

26 D. Smith and N. G. Adams, Top. Curr. Chem., 1980, 89, 1.

27 R. H. Schuler, T. I. Balkas and J. H. Fendler, J. Phys. Chem., 1971, 75, 455.

28 Y. Cao, R. F. Höckendorf and M. K. Beyer, Int. J. Mass Spectrom., 2008, 277, 206.

29 R. F. Höckendorf, O. P. Balaj and M. K. Beyer, Phys. Chem. Chem. Phys., 2011, 13, 8924. 
30 R. F. Höckendorf, O. P. Balaj, C. van der Linde and M. K. Beyer, Phys. Chem. Chem. Phys., 2010, 12, 3772.

31 C. Berg, T. Schindler, G. Niedner-Schatteburg and V. E. Bondybey, J. Chem. Phys., 1995, 102, 4870.

32 S. Maruyama, L. R. Anderson and R. E. Smalley, Rev. Sci. Instrum., 1990, 61, 3686.

33 M. K. Beyer, B. S. Fox, B. M. Reinhard and V. E. Bondybey, J. Chem. Phys., 2001, 115, 9288.

34 M. Beyer, C. Berg, H. W. Görlitzer, T. Schindler, U. Achatz, G. Albert, G. Niedner-Schatteburg and V. E. Bondybey, J. Am. Chem. Soc., 1996, 118, 7386.

35 R. C. Dunbar, Mass Spectrom. Rev., 2004, 23, 127.

36 C. Hock, M. Schmidt, R. Kuhnen, C. Bartels, L. Ma, H. Haberland and B. von Issendorff, Phys. Rev. Lett., 2009, 103, 73401.

37 W. A. Donald, R. D. Leib, J. T. O’Brien, A. I. S. Holm and E. R. Williams, Proc. Natl. Acad. Sci. U. S. A., 2008, 105, 18102.

38 M. Sena, J. M. Riveros and N. M. M. Nibbering, Rapid Commun. Mass Spectrom., 1994, 8, 1031.

39 T. Schindler, C. Berg, G. Niedner-Schatteburg and V. E. Bondybey, Chem. Phys. Lett., 1996, 250, 301.

40 P. D. Schnier, W. D. Price, R. A. Jockusch and E. R. Williams, J. Am. Chem. Soc., 1996, 118, 7178.

41 O. Hampe, T. Karpuschkin, M. Vonderach, P. Weis, Y. Yu, L. Gan, W. Klopper and M. M. Kappes, Phys. Chem. Chem. Phys., 2011, 13, 9818.

42 L. A. Curtiss, P. C. Redfern and K. Raghavachari, J. Chem. Phys., 2007, 126, 84108.

43 M. J. Frisch, G. W. Trucks, H. B. Schlegel, G. E. Scuseria, M. A. Robb, J. R. Cheeseman, G. Scalmani, V. Barone, B. Mennucci, G. A. Petersson, H. Nakatsuji, M. Caricato, X. Li, H. P. Hratchian, A. F. Izmaylov, J. Bloino, G. Zheng, J. L. Sonnenberg, M. Hada, M. Ehara, K. Toyota, R. Fukuda, J. Hasegawa, M. Ishida, T. Nakajima, Y. Honda, O. Kitao, H. Nakai, T. Vreven, J. A. Montgomery Jr, J. E. Peralta, F. Ogliaro, M. Bearpark, J. J. Heyd, E. Brothers, K. N. Kudin, V. N. Staroverov, R. Kobayashi, J. Normand, K. Raghavachari, A. Rendell, J. C. Burant, S. S. Iyengar, J. Tomasi, M. Cossi, N. Rega, J. M. Millam, M. Klene, J. E. Knox, J. B. Cross, V. Bakken, C. Adamo, J. Jaramillo, R. Gomperts, R. E. Stratmann, O. Yazyev, A. J. Austin, R. Cammi, C. Pomelli, J. W. Ochterski, R. L. Martin, K. Morokuma, V. G. Zakrzewski, G. A. Voth, P. Salvador, J. J. Dannenberg, S. Dapprich, A. D. Daniels, Ö. Farkas, J. B. Foresman, J. V. Ortiz, J. Cioslowski and D. J. Fox, Gaussian 09: Revision D.01, Gaussian, Inc., Wallingford CT, 2013.

44 S. T. Arnold, R. A. Morris and A. A. Viggiano, J. Chem. Phys., 1995, 103, 9242.

45 T. Su and M. T. Bowers, Int. J. Mass Spectrom. Ion Processes, 1975, 17, 211.

46 T. Su and M. T. Bowers, J. Am. Chem. Soc., 1973, 95, 1370.

47 T. Su and M. T. Bowers, J. Chem. Phys., 1973, 58, 3027.

48 P. Langevin, Ann. Chim. Phys., 1905, 5, 245.

49 G. Kummerlöwe and M. K. Beyer, Int. J. Mass Spectrom., 2005, 244, 84.

50 A. Akhgarnusch, R. F. Höckendorf and M. K. Beyer, J. Phys. Chem. A, 2015, 119, 9978.
51 A. Akhgarnusch and M. K. Beyer, Int. J. Mass Spectrom., 2014, 365, 295.

52 R. F. Höckendorf, K. Fischmann, Q. Hao, C. van der Linde, O. P. Balaj, C.-K. Siu and M. K. Beyer, Int. J. Mass Spectrom., 2013, 354-355, 175.

53 R. F. Höckendorf, Q. Hao, Z. Sun, B. S. Fox-Beyer, Y. Cao, O. P. Balaj, V. E. Bondybey, C.-K. Siu and M. K. Beyer, J. Phys. Chem. A, 2012, 116, 3824.

54 A. Akhgarnusch, W. K. Tang, H. Zhang, C.-K. Siu and M. K. Beyer, Phys. Chem. Chem. Phys., 2016, DOI: 10.1039/C6CP03324E.

55 W. A. Donald, R. D. Leib, M. Demireva, B. Negru, D. M. Neumark and E. R. Williams, J. Phys. Chem. A, 2011, 115, 2.

56 H. Shiraishi, G. R. Sunaryo and K. Ishigure, J. Phys. Chem., 1994, 98, 5164.

57 S. J. Blanksby and G. B. Ellison, Acc. Chem. Res., 2003, 36, 255.

58 V. B. Parker, Thermal Properties of Aqueous Uni-Univalent Electrolytes: National Standard Reference Data Series, National Bureau of Standards 2 (Category 5 - Thermodynamic and Transport Properties), Washington, DC, 1965.

59 P. J. Linstrom and W. G. Mallard, NIST Chemistry WebBook: NIST Standard Reference Database Number 69, National Institute of Standards and Technology, Gaithersburg, MD, 2005.

60 Handbook of Chemistry and Physics, ed. D. R. Lide, CRC Press, Boca Raton, 1997.

61 E. Tschuikow-Roux and S. Paddison, Int. J. Chem. Kinet., 1987, 19, 15.

62 V. Poterya, J. Kočišek, A. Pysanenko and M. Fárník, Phys. Chem. Chem. Phys., 2014, 16, 421.

63 G. Cavallo, P. Metrangolo, R. Milani, T. Pilati, A. Priimagi, G. Resnati and G. Terraneo, Chem. Rev., 2016, 116, 2478.

64 C.-R. Wang, J. Nguyen and Q.-B. Lu, J. Am. Chem. Soc., 2009, 131, 11320.

65 C.-R. Wang, K. Drew, T. Luo, M.-J. Lu and Q.-B. Lu, J. Chem. Phys., 2008, 128, 41102.

66 S. Ryu, J. Chang, H. Kwon and S. K. Kim, J. Am. Chem. Soc., 2006, 128, 3500.

67 Q.-B. Lu and L. Sanche, J. Chem. Phys., 2004, 120, 2434.

68 J. V. Coe, G. H. Lee, J. G. Eaton, S. T. Arnold, H. W. Sarkas, K. H. Bowen, C. Ludewigt, H. Haberland and D. R. Worsnop, J. Chem. Phys., 1990, 92, 3980.

69 L. Ma, K. Majer, F. Chirot and B. von Issendorff, J. Chem. Phys., 2009, 131, 144303.

70 J. R. R. Verlet, A. E. Bragg, A. Kammrath, O. Cheshnovsky and D. M. Neumark, Science, 2005, 307, 93.

71 T. Zeuch and U. Buck, Chem. Phys. Lett., 2013, 579, 1.

72 Y. Tang, H. Shen, K. Sekiguchi, N. Kurahashi, T. Mizuno, Y.-I. Suzuki and T. Suzuki, Phys. Chem. Chem. Phys., 2010, 12, 3653.

73 K. R. Siefermann, Y. Liu, E. Lugovoy, O. Link, M. Faubel, U. Buck, B. Winter and B. Abel, Nat. Chem., 2010, 2, 274.

74 W. A. Donald, M. Demireva, R. D. Leib, M. J. Aiken and E. R. Williams, J. Am. Chem. Soc., 2010, 132, 4633.

75 R. M. Young and D. M. Neumark, Chem. Rev., 2012, 112, 5553. 